\title{
Morphological Bases of DIC Syndrome in the Liver with Biliary Obstruction
}

\author{
Sadriddinov Asomidin Faizovich ${ }^{1,}$, Sheraliev Kambarali Saidalievich ${ }^{2}$ \\ ${ }^{1}$ Department of Histology and Pathological Physiology, Tashkent Pediatric Medical Institute, Tashkent, Uzbekistan \\ ${ }^{2}$ Department of Anatomy and Pathological Anatomy, Tashkent Pediatric Medical Institute, Tashkent, Uzbekistan
}

\author{
Email address: \\ asom_sad23@mail.ru (S. A. Faizovich) \\ ${ }^{*}$ Corresponding author
}

\section{To cite this article:}

Sadriddinov Asomidin Faizovich, Sheraliev Kambarali Saidalievich. Morphological Bases of DIC Syndrome in the Liver with Biliary Obstruction. International Journal of Clinical and Experimental Medical Sciences. Vol. 7, No. 5, 2021, pp. 138-142.

doi: $10.11648 /$ j.ijcems.20210705.12

Received: August 16, 2021; Accepted: September 14, 2021; Published: October 12, 2021

\begin{abstract}
Background: The development of disseminated intravascular coagulation syndrome (DIC), with liver pathologies, is usually considered a terminal condition caused by a violation of the blood coagulation system. A number of blood coagulation factors are synthesized by the liver, in this regard, the development of DIC syndrome in liver pathology is of particular importance. It is assumed that the DIC syndrome in liver pathology is caused by a violation of the coagulation properties of the blood. At the same time, local lesions of the hematocirculatory bed of the liver, as well as ultrastructural aspects of intravascular blood coagulation, remain unclear. Objective: To study the hematocirculatory bed of the liver and the features of the ultrastructure of platelet thrombi at 20-day experimental cholestasis in experimental white rats. Materials and methods: Experimental cholestasis was created in experimental rats $(\mathrm{m}=28)$ by ligation and transection of the common bile duct. The animals were sacrificed in compliance with ethical standards on days 10 and 20 of cholestasis. The liver tissue was examined by histological, corrosive, and electron microscopic methods. Results: Studies have shown that the development of DIC occurs with 20-day cholestasis, when biliary cirrhosis is formed in the liver. Some disorders of hemocirculation are observed at 10 days of cholestasis, in the form of erythrocyte sludge in the vessels of the liver. A pronounced disseminated intravascular coagulation syndrome manifests itself at 20 days of cholestasis. Disturbance of circulation is expressed in the interlobular branches of the portal system. Formed thrombi consist mainly of platelets with a minor admixture of erythrocytes and leukocytes. Ultrastructurally, a thrombus appears to be aggregated platelets, the structure of which is without significant changes. The elements of the hyalomer and granulomere are well detected in them. Most contain dense granules, some have undergone degranulation. A distinctive feature of a thrombus is the absence of fibrin filaments in the thrombus. Conclusion: Long-term experimental cholestasis, in some cases, is accompanied by a violation of the anticoagulant properties of the blood and contributes to the development of DIC. The morphological manifestation of which are platelet thrombi that arise in the interlobular veins. The ultrastructural features of these thrombi indicate an increase in the aggregation capacity of platelets, which, in combination with impaired hemostasis, probably contributes to the development of hemorrhage in liver pathology.
\end{abstract}

Keywords: Liver, Obstructive Jaundice, Intravascular Blood Coagulation, Platelet Thrombus Ultrastructure

\section{Introduction}

Due to numerous researches it was determined that the development of disseminated intravascular coagulation (DIS) syndrome at pathological conditions, was considered as the component of terminal state $[1,2]$.
Series of factors on blood coagulation were synthesized by the liver [3, 4], in this regard, the development of DIC syndrome in liver pathology acquired particular special significance. It was caused by a violation of the coagulation properties of blood [3]. At the same time, the ultrastructural aspects of intravascular blood coagulation in the hem circulatory bed of liver remains unclear. The 
internal organ of the vessels of liver and features of ultrastructure for thrombocyte in experimental obstructive jaundice were examined.

\section{Material and Research Methods}

The liver tissues of 28 rats after ligation of common bile duct were examined. On the 20th day of obturation, the experimental animals were decapitated (5 rats were control, 8 died from complications of secondary biliary cirrhosis). Keeping, killing, of experimental animals were carried out according to the ethical standards norms the instructions of "Rules for working with experimental animals." The pieces of liver tissue were processed by conventional histological and electronic microscopic methods. To study the microcirculatory liver bed, the hepatic vessels were filled with Gerota-Akilov's mass through the portal vein. After fixation in a $5-6 \%$ formalin solution for 5 days, the liver tissue was clarified by Malygin's method. Serial sections with thickness 50-80 $\mu \mathrm{m}$ were enclosed in Canadian balsam. Ultrathin sections were contrasted with uranyl acetate and lead citrate and viewed with JEM-100S electron in microscopes.

\section{Research Results}

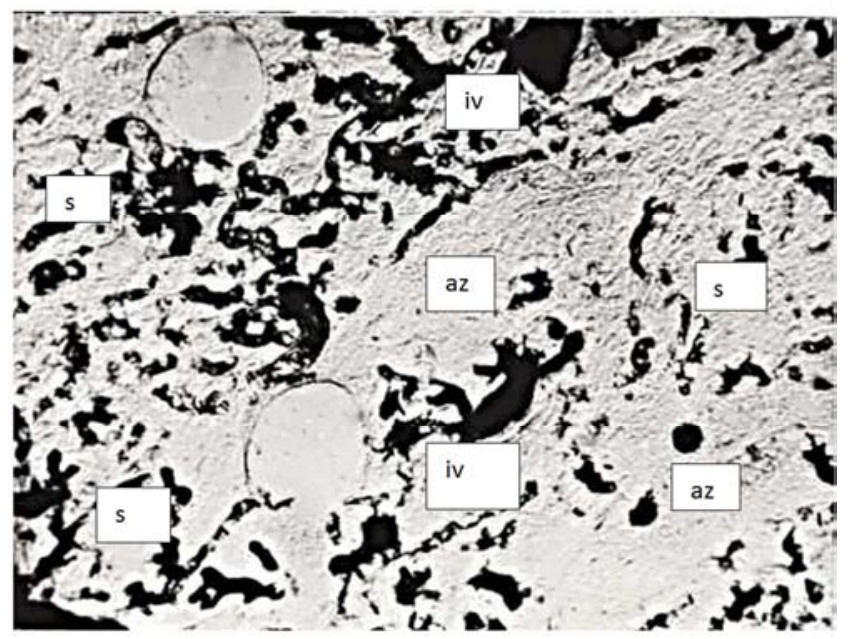

Figure 1. Rat liver on the 20th day of cholestasis. Disorganization of angioarchitectonics and the appearance of avascular zones in the liver parenchyma. Filling vessels with Parisian blue. Designation here in after: ssinusoid; iv-interlobular vein; az-avascular zones. Mag. x100.

After ligation of common bile duct on the 10th day of cholestasis, the increase of experimental animals liver occur, and at morphological examination in per portal zones in lumen, the densely aggregated erythrocytes were found in the lumen of some vessels, the thrombocyte thrombus were found in lumen larger interlobular veins, which were assessed as casuistic cases. During this period, there were no signs of portal hypertension. As the duration of cholestasis increased (20 days), the liver acquired the yellow-green shade; its mass increased twice, and in terms of $100 \mathrm{~g}$ of body weight was $6.85+0.27 \mathrm{~g}$. The stump of ligated duct was sharply expanded and contained from 2,0 to $6,0 \mathrm{ml}$ of bile. The mesenteric vessels and the portal vein were sharply filled with blood became, tense and formed venous collaterals with vessels of abdominal wall. In some animals, the ascetic fluid was found in abdominal cavity. All this indicated on development of biliary cirrhosis of liver. The morphological study of cholestasis on the 20th day, along with the characteristic changes of biliary cirrhosis, avascular areas appeared in the liver parenchyma, indicating the disorder of blood supply (Figure 1). Electron-microscopically, the destruction and disorganization of the endothelial lining of liver sinusoids appeared in these areas, and the cell necrosis occurred among the surrounding cells (Figure 2).

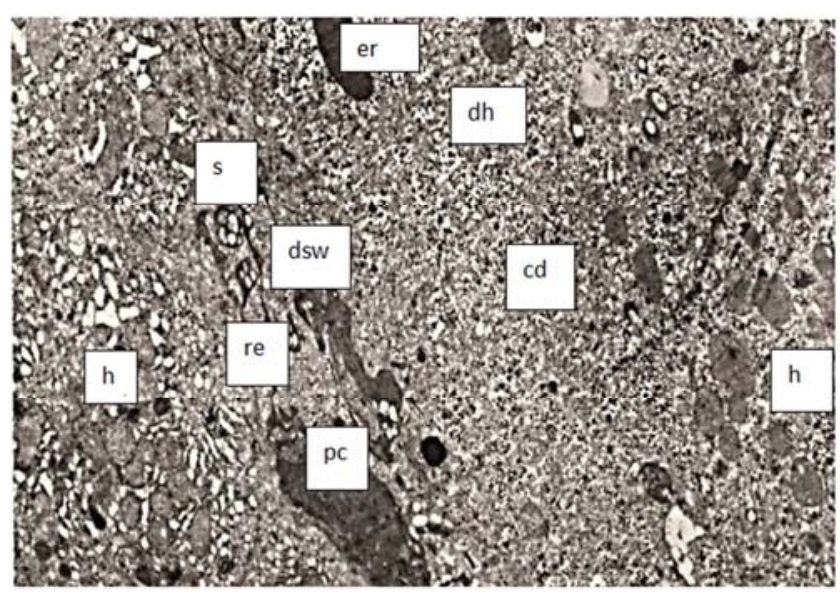

Figure 2. The same case.

Disorganization and disintegration of the endothelial lining of the sinusoid, next to the top is a dead hepatocyte with penetrated erythrocyte. On the left is an intact hepatocyte with common subcellular structures. h-hepatocyte; ssinusoid; dsw-disorganization of the sinusoid wall; cd- cell detritus; ererythrocyte; dh- dead hepatocyte; en-endothelium; re-remains of endoteliocyte; pc-pyknic cell.

At study per portal areas, the phenomena of intravascular blood coagulation were revealed, especially in the interlobular veins. Electron-microscopically, in lumen of such veins, a huge mass of aggregated blood cells at considerable distance from the vessel. Inside the vessel, the aggregated blood cells almost completely blocked the lumen of vessel, but the clear distinct little head, body, and tail of the thrombus were in vessel. The formation of thrombus in vessels of liver contributed to stagnation and development portal hypertension. According to some researchers, the portal hypertension was not caused by thrombosis of interlobular veins, but by change of structural and functional properties of vascular wall $[5,6]$. The intravascular thrombus was represented by aggregated blood cells with a predominance of platelets, detected both on longitudinal (Figure 3) and on the transverse section of vessel (Figure 4). The thrombocytes thrombus contained a small admixture of erythrocytes and leukocytes, the structure of which did not show any significant changes. The thrombus occupies the central part of vessel lumen, and between them and 
endothelium there remains a small gap, through which blood plasma apparently circulated. In the structure of the vascular wall of these areas, namely the endothelium, basal membrane and other elements, was not market. The ultrastructure of densely aggregate platelets was guide various. Many plates had irregular shape, clearly delimiting membrane, and, as usual, two zones were distinguished in them: the central one, containing granules and small vacuoles (granulomere zone), and peripheral, homogeneous and devoid of granules (hyalomeric zone). The granulomere contained granules of different structure, morphologically different from each other (Figure 4b). In thrombocytes, the ratio of granules varies sharply: some plates contained a large number of granules, in others had a little, in the thirds, they are absent altogether. A similar picture was observed at studying dense and less dense, so-called "a-granules". Dense granules had a round or oval shape with a higher electron density, and, as it indicated by some researchers [5], they contained serotonin, ADP, ATP and catecholamine's. In some plates, the lysis and clarification of granule matrix were found, which, apparently, was associated with secretion of their content in the lumen of vessel [6]. According to [7, 8], the degranulation is a sign of platelet activation. Experiments have shown that 5 minutes after platelet aggregation, labeled serotonin was released by average $49.5 \%$, which caused further aggregation of new portions of platelets [8]. The number of granules with low electron density and heterogeneous matrix was less, with the exception of a part of thrombocytes containing mainly such granules.

According to the literature [9], a-granules contained lysosome enzymes, the secretion of which led to lysis of platelets. However, in our studies, the lysis of platelets and their destruction within the thrombus were not revealed. In addition to granules, the single mitochondria, tubular structures, and few ribosomes were detected. Tubular structures probably contained $\mathrm{Ca}++$ ions (relaxation factor), the release of which promoted thickness of thrombus. At high magnifications of microscope, the fine-grained material was found on surface of the plates, which filled the spaces between the platelets, and formed a granular layer around the thrombus, which, presumably, corresponded to glycoproteins and glycolipids $[7,9]$.

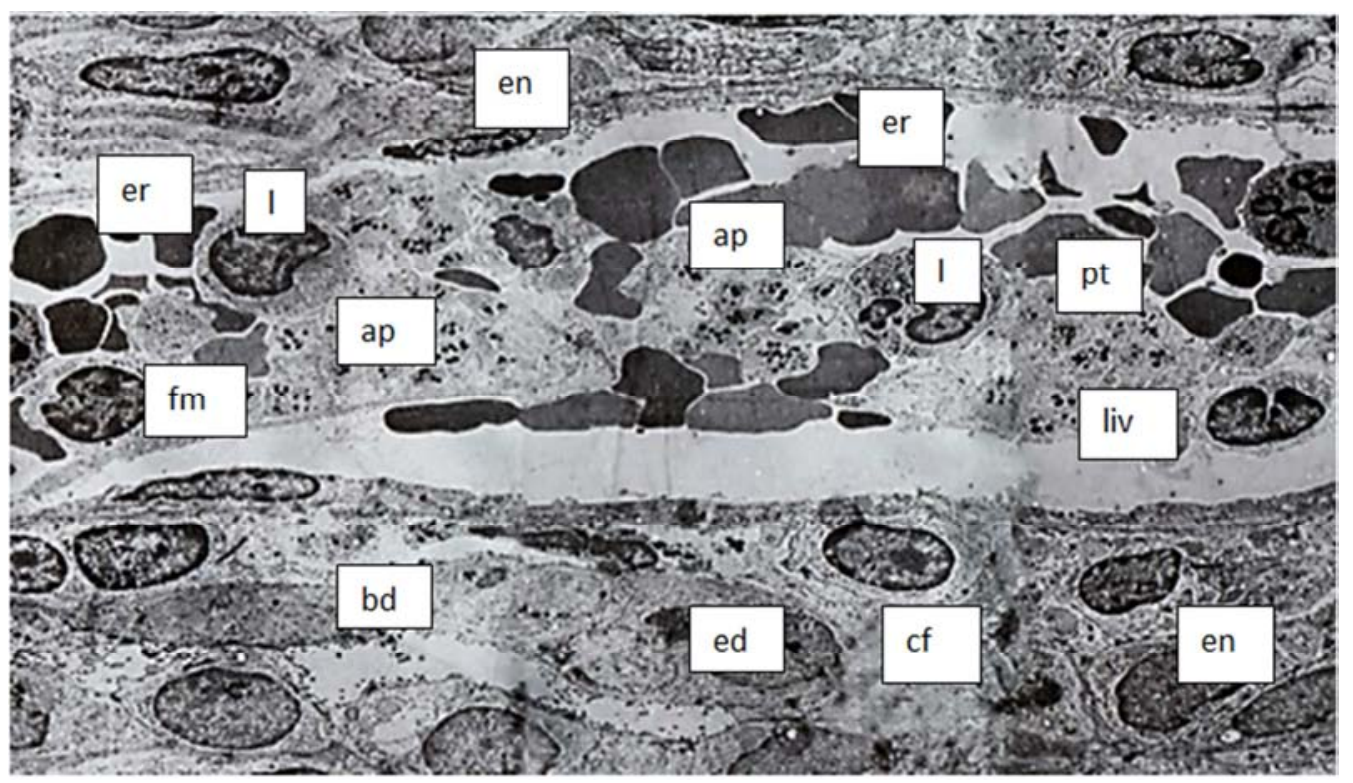

Figure 3. The same case.

Platelet thrombus in the lumen of a longitudinally cut interlobular vein. lv-lumen of the vessel; ap-aggregated platelets; bd-bile ducts; ed-epithelium of the duct; e-endothelium; 1-leukocytes; er-erythrocytes; cf-collagen fibers; fm-fine-grained material er-erythrocyte; fm-Fine-Grained material; liv-lumen of the interlobular vein; pt-platelet thrombus; 1-leukocyte. Mag. 2800.

It should be marked that there were no fibrin threads in the structure of a platelet thrombus, which was probably associated with decrease synthesis of fibrinogen by the pathologically altered liver or with increase fibrinolytic activity of blood. Experimental studies [10, 11] was shown that at threshold doses of thromboplastin the concentration of fibrinogen decreases with a simultaneous increase the fibrinolytic activity of blood. In the arteries, sinusoids, central and sub lobular veins, thrombocyte thrombus was not revealed. The data obtained accordance with the results of other authors, indicating the absence of changes in the vascular resistance of the hepatic veins in cirrhosis. The results of studies showed that with biliary cirrhosis, the intravascular blood coagulation (DIC syndrome) can develop, the morphological manifestation of which was the formation of thrombocyte thrombus, in the lumen of portal vein branches. In this case, the occurrence of blood clots was not always accompanied by the change of structure in vessel wall, and there was no fibrin in which, apparently, was the characteristic sign of liver pathology. Therefore, the mechanism occurring thrombus at mechanical jaundice was little different and was likely associated with disorder of 
blood coagulation regulatory systems. Patients with various liver pathologies had a number of disorders in coagulation system (hyper- or hypo coagulation) being associated with decrease or activation of hemocoagulation factors - thrombin, thromboxan TX, proconvertin, antithrombin III, precallikrein, plasminogen, A-antiplasmin, etc. [12-15].

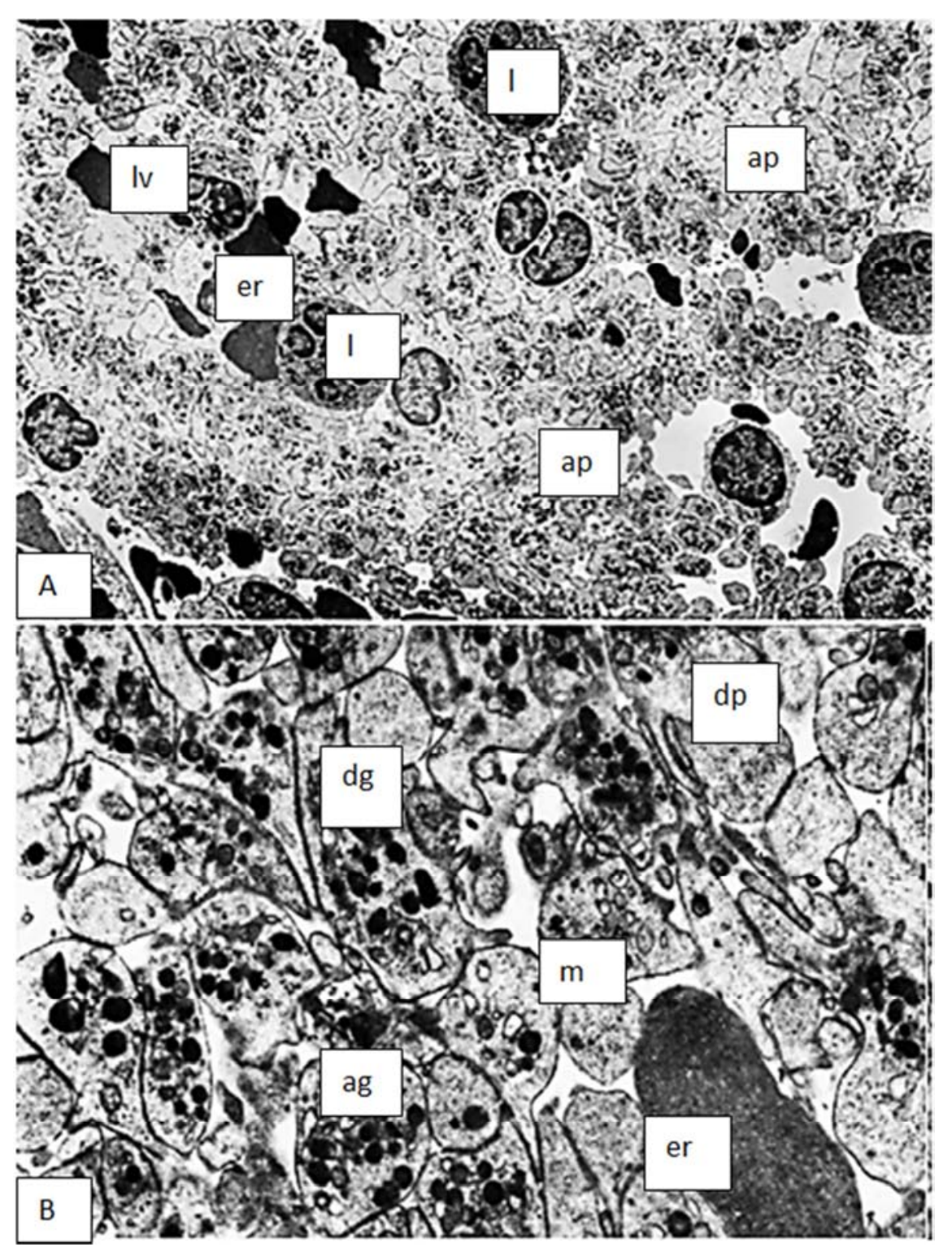

Figure 4. A. Platelet thrombus in the lumen of the transversely cut interlobular vein. Mag. 6000. B. A part of the previous figure. Mag. 10000. dpdegranulated platelets; lv-vessel lumen; dg-dense granules; m-mitochondria; ag-alpha granules;. The rest of the designations are the same as in the previous figure.

In the pathogenesis of intravascular blood coagulation in liver cirrhosis, apparently, the important place was occupied by the slowing down of blood flow in the branches of portal vein, being caused by stagnation in the biliary system. However, the reasons of increased platelet aggregation are not well understood. It can be assumed that the increased entry of tissue coagulation activators from the affected liver cells (thromboplastin) led to increased platelet aggregation. Further, activated platelets secreted ADP, serotonin, which enhanced further platelet aggregation that led to the formation of «pure thrombocyte thrombus». However, due to disorder of fibrinogen synthesis or the activation of anticoagulant system as formation of complex of heparin composition the thrombus formation is became in completed $[9,12]$. At the result of decrease the functionally active thrombocytes from the vascular bed, and, also the above mentioned disorders in the hemostasis, the hypo coagulation has been developed which was naturally for cirrhosis of liver. At the result of the loss of functionally active platelets from the vascular bed, as well as the above-described disorders in the hemostasis system, hypo coagulation develops characteristic cirrhosis of liver.

\section{Conclusion}

Thus, the long-term experimental cholestasis leading to the 
development of biliary cirrhosis of the liver was accompanied in some cases by disorder of the anticoagulant blood properties and promoted to development of DIC syndrome. The morphological manifestation of this process in the liver was thrombocytes thrombus, being localized in interlobular veins, and was one of the possible causes of portal hypertension. The detected ultrastructural features of thrombus witness on increase aggregation ability of platelets, which, in combination with hemostasis system, disorder was apparently one of the factors causing hemorrhages at liver pathology.

\section{References}

[1] Цвирко Д. Г., Змачинский В. А., Смирнова Л. А. Диагностика и лечение диссеминированного внутрисосудистого свертывания крови. Медицинские новости.-2018. №5 C. 47-51 [Tsvirko D. G., Zmachinsky V. A., Smirnova L. A. Diagnostics and treatment of disseminated intravascular coagulation. Medical news.-2018. №5 p. 47-51].

[2] Альфонсов В. В. Механизмы развития морфологического эквивалента ДВС-синдрома / В. В. Альфонсов, Е. В. Альфонсова // Тромбоз, гемостаз и реология. — 2010. № 1. - C. 44-51. [Alfonsov V. V. Mechanisms of development of the morphological equivalent of DICsyndrome / V. V. Alfonsov, E. V. Alfonsova // Thrombosis, hemostasis and rheology. - 2010. - No. 1. - P. 44-51].

[3] Баркаган 3. С. Гемостаз. В кн.: Руководство по гематологии. Т. 3. Под редакцией А. И. Воробьева. 3-е изд., перераб. и доп. М., Ньюдиа-мед; 205. С. 9-147 [ Barkagan Z. S. Hemostasis. In the book: Guide to Hematology. Vol. 3. Edited by A. I. Vorobyov. 3rd ed., Rev. and add. M., Nudiamed; 205. p. 9-147].

[4] Момот А. П., Мамаев А. Н. Современные аспекты патогенеза, диагностики и терапии ДВС-синдром. Клиническая медицина, 2008, Т1, № 1. С. 63-68. [Momot A. P., Mamaev A. N. Modern aspects of the pathogenesis, diagnosis and therapy of DIC syndrome. Clinical medicine, 2008, V1, No. 1. p. 63-68].

[5] Зербино Д. Д., Лукасевич Л. Л. Диссеминированное внутрисосудистое свертывание крови.: факты и концепции / Д. Д. Зербино, Л. Л. Лукасевич. - М.: Медицина, 1989. 255. [Zerbino D. D., Lukasevich L. L. Disseminated intravascular coagulation.: facts and concepts / D. D. Zerbino, L. L. Lukasevich. - M.: Medicine, 1989. --255].

[6] Гуляева И. Л., Пестренин Л. Д., Логунов, А. В., Булатова И. А. Патология гемостаза и эндотелиальная дисфункция при гепатите В: современное состояние вопроса. 2017, № 4. С. [Gulyaeva I. L., Pestrenin L. D., Logunov A. V., Bulatova I. A. Pathology of hemostasis and endothelial dysfunction in hepatitis B: current state of the art. 2017, No. 4. P].
[7] Carey M. J., Rodgers G. M. Disseminated intravascular coagulation: clinical and laboratory aspects // Am. J. Hematol. - 1998; 59 (1): 65-73. https://doi.org/10.1002/(sici)10968652(199809)59:1<65::aid-ajh13>3.0.co;2-0.

[8] Levi M., de Jonge E., van der Poll T. New treatment strategies for disseminated intravascular coagulation based on current understanding of the pathophysiology // Ann. Med. - 2004; 36 (1): 41 https://doi.org/10.1080/07853890310017251.

[9] Шабалина А. А., Костырева М. В., Танашян М. М. Укутанные тромбоциты - новые возможности лабораторной диагностики нарушений тромбообразования // Анналы клинической и экспериментальной неврологии. - 2015. - Т. 9, № 3. C. 56-60. [Shabalina A. A., Kostyreva M. V., Tanashyan M. M. Wrapped platelets - new possibilities of laboratory diagnosis of thrombus formation disorders // Annals of Clinical and Experimental Neurology. - 2015. - V. 9, No. 3. - P. 56-60].

[10] Gando S. Disseminated intravascular coagulation in trauma patients // Semin. Thromb Hemost. - 2001; 27 (6): 585-92. https://doi.org/10.1055/s-2001-18864.

[11] Дзяк Г. В. Фракционированные и нефракционированные гепарины в интенсивной терапии / Г. В. Дзяк, Е. Н. Клигуненко, В. И. Снисарь - М.: Медпресс-информ, 2005. [Dzyak G. V. Fractionated and unfractionated heparins in intensive care / G. V. Dzyak, E. N. Kligunenko, V. I. Snisar M.: Medpress-inform, 2005].

[12] Никонов В. В., Соколов А. С. и др. Тромбозы и эмболии в практике врача догоспитального этапа. - Харьков, 2018. - 300 c. [Nikonov V. V., Sokolov A. S. and others. Thrombosis and embolism in the practice of a doctor before the hospital stage. - Kharkiv, 2018. -- 300 P].

[13] Мамот А. П. Современные аспекты патогенеза, диагностики и терапии ДВС-синдрома / А. П. Мамот, А. Н. Мамаев // Клиническая онкогематология. Фундаментальные исследования и клиническая практика. - 2008. - T. 1, № 1. - C. 63-71. P. [Mamot Modern aspects of the pathogenesis, diagnosis and therapy of disseminated intravascular coagulation / A. P. Mamot, A. N. Mamaev // Clinical hematology oncology. Basic research and clinical practice. - 2008. - V. 1, No. 1. - P. 63-71].

[14] Кузник Б. И. Система гемостаза // Физиология человека / Под ред. В. М. Покровского, Г. Ф. Коротько. - М.: Медицина, 2000. - T. 1. - С. 313-325. - 448 c.[Kuznik B. I. System of hemostasis // Human Physiology / Ed. V. M. Pokrovsky, G. F. Shortly. - M.: Medicine, 2000.-- T. 1. - S. 313-325. $-448 \mathrm{p}]$.

[15] Becker J. U., Wira C. R. Disseminated Intravascular Coagulation. http://www.emedicine.medscape.com/article/779097. 